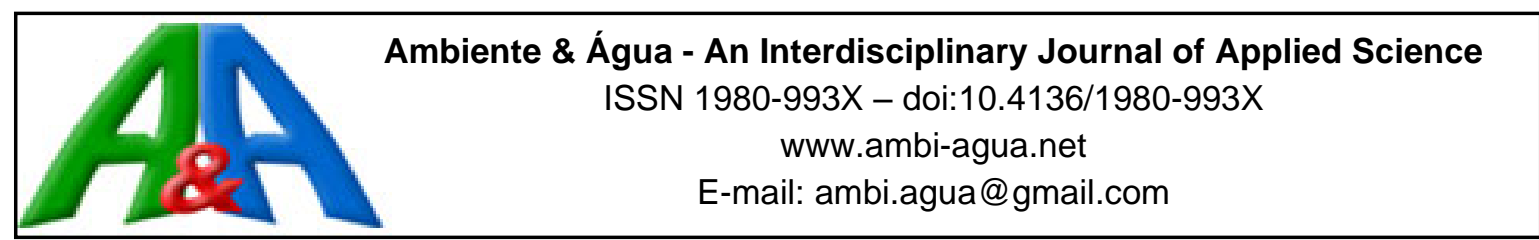

\title{
Future scenarios (2021-2050) of extreme precipitation events that trigger landslides - a case study of the Paraitinga River watershed, SP, Brazil
}

\author{
ARTICLES doi:10.4136/ambi-agua.2558
}

Received: 14 Aug. 2020; Accepted: 21 Sep. 2020

\author{
Rodrigo Cesar da Silva ${ }^{1,2^{*}(\mathbb{D})}$; Rodolfo Moreda Mendes ${ }^{1(\mathbb{D})}$; Gilberto Fisch ${ }^{1(\mathbb{L})}$ \\ ${ }^{1}$ Programa de Pós-Graduação em Ciências Ambientais (PPGCA). Universidade de Taubaté (UNITAU), \\ Estrada Municipal Doutor José Luiz Cembranelli, n5000, CEP: 12081-010, Taubaté, SP, Brazil. \\ ${ }^{2}$ Programa de Pós-Graduação em Desastres Naturais. Universidade Estadual Paulista "Júlio de Mesquita Filho" \\ (UNESP-CEMADEN). Estrada Municipal Altino Bondesan, n500, CEP: 12247-016, \\ São José dos Campos, SP, Brazil. \\ E-mail: rodolfo.mendes@cemaden.gov.br, gilberto.fisch@unitau.br \\ "Corresponding author. E-mail: rodrigo.peb@gmail.com
}

\begin{abstract}
Global climate change and the consequent occurrence of extreme events will impact societies on a large-scale, with intense rainfall tending to trigger a greater number of hazards caused by climatic events, especially landslides. The incidence of this type of event is conditioned by the combination of several environmental and human factors, such as land use and cover patterns, geomorphological characteristics, and extreme climate. This study analyzed, through the classification of land use and cover and simulation of rainfall, future scenarios in the Paraitinga River watershed, in the southeastern region of Brazil. Precipitation data were used from the MIROC5/Eta model, using the scenario RCP 4.5 (Representative Concentration Pathway) from the IPCC (Intergovernmental Panel on Climate Change) and comparing data from past (1971-2000) and future (2021-2050) periods. The results estimate an increase in consecutive dry days and intense and very intense rainfall, pointing to heavy and concentrated rainfall in the future. An increase of $31.8 \%$ in accumulated precipitation over 72 hours that triggers landslides was also predicted, and this increase encompasses $41.6 \%$ of the areas of medium and high frequency of incidence of this type of geological event in the study area.
\end{abstract}

Keywords: Atlantic Forest, climate simulation, MIROC5/Eta.

\section{Cenário futuro (2021-2050) dos extremos de precipitações que desencadeiam deslizamentos de massa - estudo de caso da bacia do Rio Paraitinga, SP, Brasil}

\section{RESUMO}

As mudanças climáticas globais e a consequente ocorrência de eventos extremos impactarão toda a sociedade, sendo que chuvas intensas tendem desencadear maior quantidade de perigos climáticos, destacando-se os movimentos de massa. A incidência deste tipo de evento está condicionada a conjugação de diversos fatores ambientais e humanos, tais como padrão de uso e ocupação do solo, características geomorfológicas e aspectos climáticos 
extremos. Para tanto, este estudo buscou analisar, por meio da classificação de uso e ocupação do solo e de simulação climática das precipitações, os cenários futuros na bacia hidrográfica do rio Paraitinga, na região sudeste do Brasil. Os dados de precipitação foram gerados pelo modelo MIROC5/Eta, utilizando o cenário RCP 4.5 (Representative Concentration Pathway) do IPCC (Intergovernmental Panel on Climate Change) e comparando dados do período passado (19712000) e futuro (2021-2050). Os resultados estimam um aumento de dias consecutivos secos e precipitações intensa e muito intensa, apontando para chuvas fortes e concentradas no futuro. Apontam ainda para o aumento de $31,8 \%$ nas precipitações acumuladas de três dias que desencadeiam movimentos de massa, sendo este acréscimo de 41,6\% nas áreas de média e alta frequência de incidência deste tipo de evento geológico na área de estudo.

Palavras-chave: Mata Atlântica, MIROC5/Eta, simulação climática.

\section{INTRODUCTION}

Natural disasters related to landslides occur around the world and the losses related to such events range from loss of vegetation, soil and even cases involving deaths in urban areas (Silva et al., 2014). Landslides can be related to a combination of several natural and man-made factors, including land use and occupation, terrain slope and intense rainfall.

In the Serra do Mar region, Brazil, a study by Vieira et al. (2018) on the susceptibility and evaluation of models for predicting the occurrence of landslides points out that the existence of susceptible and prone areas for the occurrence of this event is related to local topography, slope angle and landforms. Regions with smooth relief and inclination up to $30^{\circ}$ have low susceptibility, while areas with an inclination greater than $40^{\circ}$ and $400 \mathrm{~m}$ in altitude are very unstable and conducive to the triggering of landslides.

Batista and Julien (2019) point out that the areas with the highest occurrence of landslides are related to the highest levels of precipitation (whether of convective or frontal origin), with the slope and angle of the terrain having a strong influence on the outbreak of landslides.

When comparing the increase of urbanization in areas with high slope in California and on the coast of southeastern Brazil, Oliveira-Folharini et al. (2018) point out that in both countries the population's vulnerability to landslides is increasing. This is due to the expansion of occupation in high-risk areas, mainly due to precarious construction in Brazilian municipalities, where there is disorderly and unplanned urbanization. This fact is a consequence of poverty and poor living conditions and will tend to affect an increasing number of inhabitants, since climate simulation models predict more intense rains during the summer period.

Mendes et al. (2017) carried out an analysis of landslides in the municipality of São José dos Campos in March 2016 and concluded that precipitation alone would not be enough to trigger the registered landslides. The authors concluded that anthropogenic factors affecting the terrain have a strong influence on the triggering of landslides, with emphasis on cuts on slopes with highly inclined terrain, on cuts into landforms with steep inclination and on water overflow on slopes due to the leaking of large-volume domestic water storage boxes.

Soil moisture, probabilistic mathematical models, stability analysis and local geotechnical parameters must be considered in the analysis of landslide deflagration. When analyzing the occurrence of landslides in the municipality of Campos do Jordão/SP in the beginning of 2000, Mendes et al. (2018) considered natural and anthropogenic factors. The results showed that the volume of precipitation and the geotechnical conditions were not enough to trigger the landslides, which caused 10 deaths, but rather this was due to anthropogenic factors, such as cuts along the slope, inadequate construction practices, and leaking pipes. The results also point out that the current Civil Defense and CEMADEN alert systems would be suitable for alerting to the events that occurred in the early 2000 s, but that the combination of previous precipitation 
and pipe leakage left the soil close to moisture saturation at the beginning of the rainy season, thus triggering landslides.

König et al. (2019) developed a study in the city of Campos do Jordão/SP analyzing the occurrence of landslides caused by anthropic modification of the relief, using the Shalstab mathematical model and WorldView-2 high resolution satellite scenes. The geotechnical parameters loaded into the Shalstab model identified the land stability classes along an urban slope in a promising way, similar to those in existing risk maps. However, in areas classified as stable it was possible to identify landslide scars through satellite scenes, from which it was also possible to identify that anthropic actions are responsible for triggering landslides, highlighting bare soil, sparse vegetation, inadequate building standards, vertical cuts on the slopes, weight overload, and leakage of pipes that induce landslides in urban areas.

The continuous excessive emission of greenhouse gases and their respective concentration in the atmosphere is continuously reaching higher levels, with $413 \mathrm{ppm}$ of $\mathrm{CO}_{2}$ registered in April 2020 (NOAA, 2020). This may generate a series of risks such as a threat to unique natural systems, occurrence of extreme events and events that are still unknown, and expansion of the distribution of impacts associated with extreme events. These changes can generate a series of impacts added to those related to climate change (Silva Dias, 2014).

When analyzing climate change in Brazil, Marengo (2014) indicated that changes of different magnitudes are projected for the Brazilian territory, even though global climate models have uncertainties in their simulations. The results indicate that the southeastern region of Brazil tends to present an increase in average temperatures and extreme rainfall events, which may trigger an increase in the occurrence of natural disasters such as floods and landslides.

Under the assumption that regions with hills, mountains and anthropogenic interference are more susceptible to the occurrence of natural disasters, with emphasis on landslides, this study analyzes the future changes in accumulated precipitation that triggers natural disasters related to landslides in the Paratinga River watershed, state of São Paulo, Brazil.

\section{MATERIAL AND METHODS}

\subsection{Study area}

This study was carried out in the Paraitinga River watershed (Figure 1), located in the Vale do Paraíba region, state of São Paulo, Brazil, with a total area of 2,785.4 $\mathrm{km}^{2}$. The confluence of the Paraitinga and Paraibuna Rivers form the Paraíba do Sul River, one of the most important in the country, which is about $1,180 \mathrm{~km}$ in length, and the damming of these rivers forms the Paraibuna Dam (Marengo and Alves, 2005).

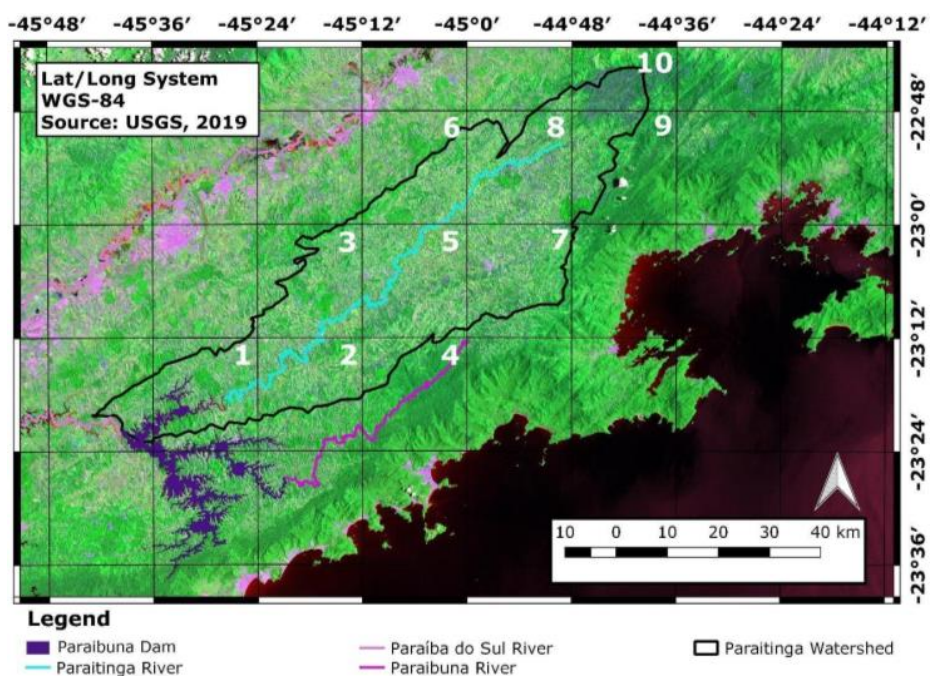

Figure 1. Study area and climate simulation grids. 
The region has Serra do Mar mountains in its southern and eastern portion as the limit of the watershed with mountainous areas that reach 1,600 $\mathrm{m}$ in altitude, to the northeast is Serra da Bocaina mountains with altitudes that exceed 2,000 $\mathrm{m}$ and in the center is the Paraitinga River. In the northern region is the Serra de Quebra-Cangalha mountains with altitudes that can reach $1,450 \mathrm{~m}$ in altitude. This geographical region is called Plateaus and Sierra of EastSoutheast Atlantic (Ab'Saber, 2003) and presents intense atmospheric turbulence due to its geographic formation, causing great spatial variability of rainfall (Silva and Simões, 2014).

\subsection{Climate simulation data}

The data used in this research were daily precipitation, generated by climate simulation using the MIROC5 model, regionalized by the Eta model. The resolution grid used was 20x20 km, using the scenario RCP 4.5 (Representative Concentration Pathway) as a reference, with precipitation being homogeneous throughout the simulated area. The climate simulation data has been evaluated in previous studies, demonstrating that there are uncertainties inherited from global climate models related to mountainous areas (Chou, 2014a) and the radiation balance at the top of the atmosphere where there are incoming short waves (SW) and outgoing long waves (LW) that vary between climate simulation models and observational estimates (Watanabe et al., 2010).

The MIROC5 climate model (Model for Interdisciplinary Research on Climate, Version 5) was developed in Japan, and the model has $256 \times 224$ global simulation grids, with 49 atmospheric vertical levels (Watanabe et al., 2010). The Eta downscaling regionalization model is available at CPTEC/INPE (Brazil) for climate change studies (Chou et al., 2014a).

The precipitation data were compared by simulation grid, and periods were analyzed using Pearson's Correlation Test, which is an adequate measure to assess the degree of linear association between two different variables (Silvestre, 2016).

Two temporal cut-offs were considered, one from a past period (1971-2000) and another from a future period (2021-2050). The region was spatialized with points numbered 1 to 10 , and grid $\mathrm{P}_{4}$ was disregarded in this research (Figure 1) because it is outside the drainage area of the hydrographic basin. This spatialization method is similar to that used by Silva et al. (2019).

\subsection{Topographic maps}

To produce topographic maps and the delimitation of the Paraitinga River watershed, declivity data extracted from the TOPODATA Project database was used, with $30 \mathrm{~m}$ of spatial resolution (INPE, 2019), a product that is derived from the SRTM (Shuttle Radar Topography Mission). Through these scenes, a hypsometry model was created and contour lines with $25 \mathrm{~m}$ equidistance were generated to delimit the ridging lines and a 3D model of the research area (Figure 2).

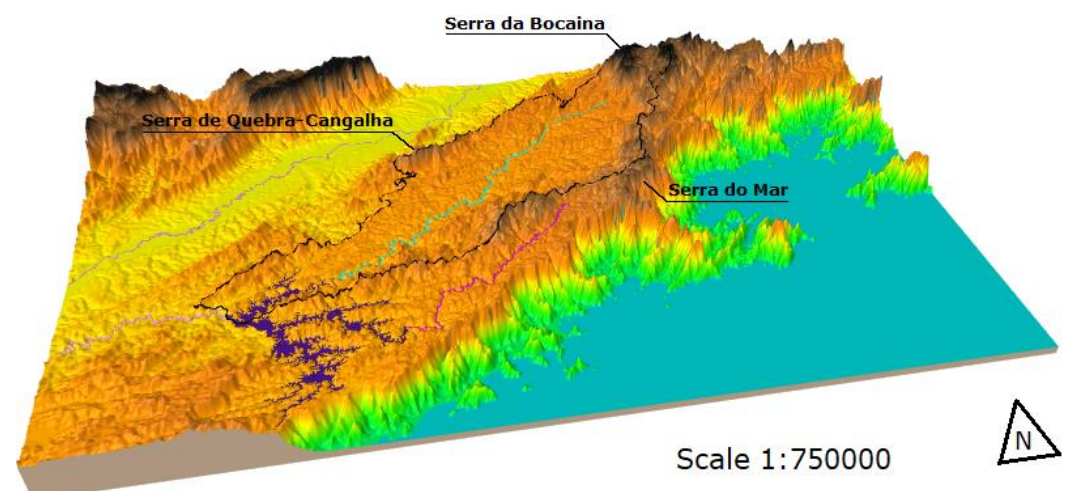

Figure 2. 3D model of the study area. 
For the delimitation of the Paraitinga watershed, a scene from the Landsat 8 Satellite OLI sensor, with $30 \mathrm{~m}$ of spatial resolution was used (USGS, 2019). Topographical maps of the Brazilian Institute of Geography and Statistics (IBGE) were also used, on a scale of 1:50,000 (Table 1). These maps were registered to the georeferenced project and a mosaic was built for the correct delimitation of the Paraitinga watershed.

Table 1. Topographic maps to delimit the Paraitinga River watershed

\begin{tabular}{cccc}
\hline Maps & Maps code & Projection & Datum \\
\hline São José do Barreiro & SF-23-Z-A-IV-2 & UTM Zone 23 & Córrego Alegre \\
Rio Manbucaba & SF-23-Z-A-IV-4 & UTM Zone 23 & Córrego Alegre \\
Guaratinguetá & SF-23-Y-B-VI-4 & UTM Zone 23 & Córrego Alegre \\
Lagoinha & SF-23-Y-D-III-2 & UTM Zone 23 & Córrego Alegre \\
\hline
\end{tabular}

Source: IBGE (2019).

\subsection{Delimitation of landslide risk areas}

For the delimitation of landslide risk areas, the reports of the Integrated Plan for Water Resources of the Paraíba do Sul River Basin were used, produced by AGEPAP (Water Management Association of the Paraíba do Sul River watershed), in the section Vulnerable Areas and Extreme Critical Events (AGEVAP, 2013). From this report and its cartographic bases, the risk areas in the Paraitinga watershed basin were defined, based on the occurrence of landslides, with: i) low frequency, ii) medium frequency, and iii) high frequency (AGEVAP, 2013).

Maps of land use and land cover were constructed to identify areas of human occupation on steep slopes, which are susceptible to landslides. According to Camarinha et al. (2014), areas not occupied by human activities and which have native vegetation cover have a low risk of landslides, while mountainous areas with high declivity and human occupation have a high risk of accidents.

From the slope maps generated to delimit the area of Paraitinga River watershed, the region was separated into three distinct categories according to slope. Based on the results obtained by Vieira et al. (2010), we classified: i) stable areas (inclination up to $30^{\circ}$ ); ii) medium stability area (inclination between 31 and $39^{\circ}$ ) and; iii) unstable areas (inclination greater than $40^{\circ}$ ).

\subsection{Land use and land cover and future scenarios}

Land use and land cover (LULC) has a strong influence on the occurrence of natural disasters related to landslides (Hughes and Schulz, 2020). In order to understand the dynamics of the occupation of the Paraitinga watershed, two LULC maps were produced, for the years 2002 and 2019, using the software ArcGIS 10.3 (https://www.arcgis.com/index.html).

The satellite used to generate the LULC maps of 2002 was the Landsat 7, ETM + sensor with a $30 \mathrm{~m}$ spatial resolution, path 218 , row 076 , acquired on October 15,2002 . For the LULC map of 2019 the Landsat 8 satellite's OLI sensor was used, with $30 \mathrm{~m}$ of spatial resolution. The scene was acquired on October 13, 2019, path 218, row 76. Both scenes underwent an atmospheric correction process for the multi-temporal comparison between the sensors (Chander et al., 2009; Vermote et al., 2016).

Both LULC maps were classified using five categories: i) native vegetation, ii) reforestation, iii) urbanization/bare soil, iv) water bodies and, v) fields/pastures. The fields/pastures classification is a general classification that combines areas based on a predominance of hills and mountains which have low aptitude for agricultural activities.

For the land use change (LUC) simulation in 2036, the maps produced in ArcGIS 10.3 were exported to the Qgis 2.18.0 software (https://qgis.org/en/site/) and simulated by the MOLUSCE 3.0.13 plugin (https: //plugins.qgis.org/plugins/molusce/). The Modules for Land 
Use Change Simulations (Molusce) Plugin was produced based on technological cooperation between Nextgis and Asia Air Survey and aims to analyze land-use changes and create future scenario maps through simulation (NEXTGIS, 2020).

The MOLUSCE Plugin implements three processes for the simulation of land-use change: i) separates the raster categories in period A (past), period B (present) and generates rasters of the variables between the analyzed periods (change maps); ii) trains the model that predicts changes between the past and the present; iii) predicts future changes using derived models (MOLUSCE, 2020).

\subsection{Determination of extreme rainfall and frequency of occurrence}

For determination of extreme rainfall, the Quantis technique was used, which was initially developed by Pinkayan (1966). According to Xavier et al. (2002), the Quantis technique is a method based on a series of precipitation data (x), and the Quantis (Qx) represents a percentage variation of precipitation $(\mathrm{x})$ as a function of $(\mathrm{Q})$, defined by Equation 1:

$$
F(x)=P[X \leq x]
$$

When $\mathrm{F}(\mathrm{x})$ is known for $\mathrm{x} 1, \mathrm{x} 2, \mathrm{x} 3, \mathrm{x} 4$ and $\mathrm{x} 5$, the Quantis are determined. This technique was used to determine heavy and very heavy daily rainfall, analyzing the variation in precipitation for the past period (1971-2000) and classifying daily rainfall for the future period (2021-2050).

The monthly and annual precipitation frequency was calculated using the R95p, CDD, Rx5day index, developed by ETCCDI (Expert Team on Climate Change Detection and Indices), using the ClimPACT2 index standardization software (Alexander and Herold, 2016). The definition of the indices (Zhang and Yang, 2004; Alexander, 2016 and Alexander et al., 2019) is shown in Table 2:

Table 2. Definition of the ETCCDI index.

\begin{tabular}{ccccc}
\hline ID & ID name & ID definition & Equation & Units \\
\hline CDD & Consecutive dry days & $\begin{array}{c}\text { Maximum number of consecutive } \\
\text { days less than 1 mm }\end{array}$ & $R R i j<1 \mathrm{~mm}$ & Day \\
R95p & Very wet days & $\begin{array}{c}\text { Annual total daily precipitation } \\
\text { greater than the 95 }\end{array}$ & $R 95 p j=\sum_{w=1}^{W} R R w j$ & $\mathrm{~mm}$ \\
Rx5day & $\begin{array}{c}\text { Maximum 5-day } \\
\text { precipitation amount }\end{array}$ & $\begin{array}{c}\text { Monthly maximum consecutive 5- } \\
\text { day precipitation greater than 1 } \mathrm{mm}\end{array}$ & $\begin{array}{c}\text { where: } R R w j>R \text { R } \\
\text { Rayj }=(R R k j)\end{array}$ & $\mathrm{mm}$ \\
\hline
\end{tabular}

\subsection{Definition of critical thresholds for landslide deflagration}

The definition of precipitation thresholds that trigger landslides is complex, since their outbreak depends on a combination of several factors, including the geological structure of the terrain, the slope of hills, precipitation and especially the anthropic inducing factors.

The southeastern region of Brazil, especially the mountainous areas of São Paulo state, has great propensity for the occurrence of natural disasters such as landslides (Almeida et al., 2016). Santoro et al. (2010) analyzed the occurrence of landslides in São Paulo State (regions of Campinas, Baixada Santista, Litoral Norte, Sorocaba, ABCD Paulista and Vale do Paraíba) and demonstrated a high correlation between terrain conditions, anthropic inducing factors and precipitation accumulated over 72 hours, and the occurrence of landslides, and the results of this research were adopted by the Preventive Civil Defense Plan (PPDC) of São Paulo state as a threshold for the outbreak of landslides.

According to Tatizana et al. (1987a) landslide susceptibility is highly variable in the 
various sectors of the Serra do Mar mountains, reflecting variations in conditions such as geology, geomorphology, slope, vegetation cover, rainfall, and slope position. The relationship between rainfall and landslides can be given by Equation 2, and the Critical Precipitation Coefficient (CPC) by Equation 3.

$I(A c)=k \cdot A c^{-0.933}$

Where:

I: Sufficient intensity for landslide outbreak

Ac: Accumulated precipitation in the previous four days

$K$ : Constant dependent on the geotechnical conditions of slopes and the intensity of landslides

$$
C P C=\frac{l i}{K} \cdot A c i^{-0.993}
$$

Where:

\section{$L i$ : Intensity of hourly precipitation}

Aci: Accumulated precipitation in the previous four days

Tatizana et al. (1987b) applied equations relating precipitation and landslides and defined a landslide zone for the municipality of Cubatão/SP, located in the Serra do Mar mountains, which was divided into four distinct zones: induced landslides, sparse landslides, generalized landslides and mud landslides.

In an analysis of landslides in the municipality of São Bernardo do Campo/SP, Molina et al. (2015) demonstrated that the cumulative precipitation considered sufficient to trigger landslides is $50 \mathrm{~mm}$ in one day, $80 \mathrm{~mm}$ in two days, $120 \mathrm{~mm}$ in three days and $150 \mathrm{~mm}$ in four days. Rainfall above $100 \mathrm{~mm}$ is enough to trigger landslides without accumulating precipitation in the previous days.

Mendes et al., (2015) studied the occurrence of landslides in the municipality of São José dos Campos/SP and reported that rainfall between 20 to $50 \mathrm{~mm}$ in $24 \mathrm{~h}$ and $50 \mathrm{~mm}$ in $72 \mathrm{~h}$ are fundamental to triggering induced landslides in the study area. Furthermore, this critical threshold of rainfall is related to various inducing factors such as cut slopes and embankments caused by houses built in the region.

Oliveira et al. (2016) applied the equations proposed by Tatizana et al., (1987b) to the municipality of Nova Friburgo/RJ and confirmed the relationship between accumulated precipitation and landslides. However, they emphasized that a mud landslide is very restricted in occurrence and is associated with major disasters. Thus, their results point out the occurrence of induced landslides with thresholds of $40 \mathrm{~mm}$ in one day, $60 \mathrm{~mm}$ in two days, $80 \mathrm{~mm}$ in three days and $100 \mathrm{~mm}$ in four days.

Considering the exposure to landslides in the Vale do Paraíba, we adopted as rainfall thresholds for triggering landslides the same ones used by the Civil Defense Plan of São Paulo State, established by Resolution CMIL/CEPDEC 21-610 (São Paulo, 2019), with reference in the study of Santoro et al. (2010), which defines the thresholds for the Vale do Paraíba at 60 $\mathrm{mm}$ in $24 \mathrm{~h}, 80 \mathrm{~mm}$ in $48 \mathrm{~h}$ and $100 \mathrm{~mm}$ in $72 \mathrm{~h}$. These thresholds vary according to the geographic region of São Paulo state. 


\section{RESULTS AND DISCUSSION}

\subsection{Analysis of landslide risk areas}

Through the interpolation of data generated from AGEVAP (2013), Vieira et al. (2010) and the construction of LULC maps the areas susceptible to landslides was estimated (Figure 3). In the Paraitinga watershed, the municipality of Paraibuna presents medium frequency of landslides, and São Luís do Paraitinga has a high frequency (AGEVAP, 2013).

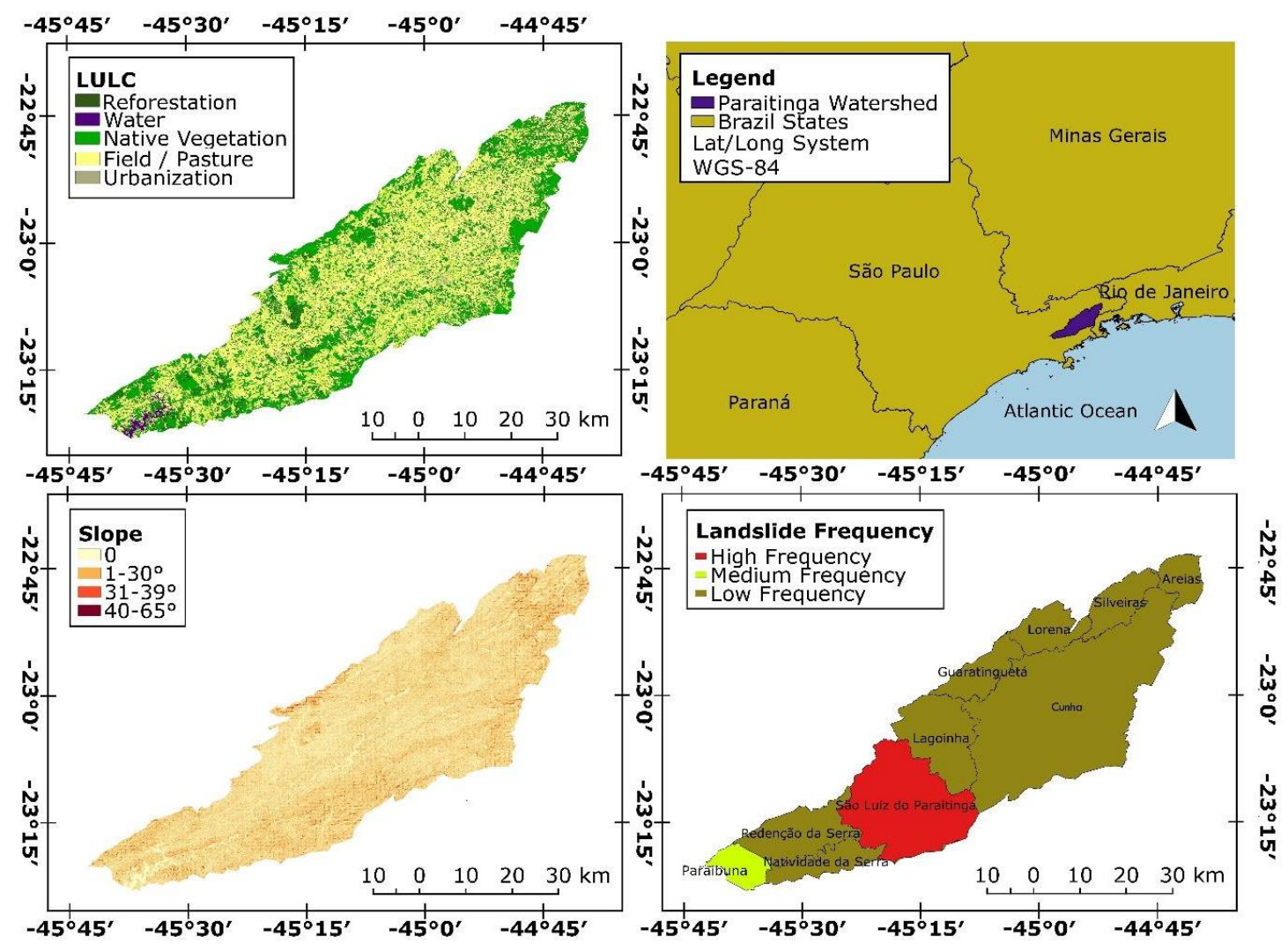

Figure 3. LULC (2019), slope relief and landslide frequency in the Paraitinga Watershed.

The LULC in the Paratinga River Basin in 2019 was fields and pastures (53.4\%), native vegetation $(28.7 \%)$, reforestation $(8.8 \%)$, urbanization and bare soil $(8.4 \%)$ and water bodies $(0.7 \%)$. The mapping of LULC in 2002 was also carried out and the variation between 2002 and 2019 was used for future projection.

LULC underwent significant changes between the years 2002 and 2019, with a strong increase in the presence of urbanization and bare soil $(221.0 \%)$, with most of this increase relative to bare soil due to urbanization processes, which represents a reduction in the quality of land use in the region. There was a significant increase of reforestation (158.2\%), with a decrease in fields and pastures $(-17.7 \%)$ and water bodies $(-5.2 \%)$, and there was practically no change in native vegetation $(1.1 \%)$.

From the LULC maps of the years 2002 and 2019, the year 2036 was simulated using the Molusce algorithm. The simulation demonstrates little difference between the years 2019 and 2036, with an increase in reforestation (6.0\%), and urbanization and bare soil (1.9\%). There was no change in fields and pastures, and a decrease in water bodies $(-8.3 \%)$ and native vegetation $(-2.2 \%)$ (Table 3$)$.

The simulation of land use and occupation predicts that in the future there will be a tendency to maintain the characteristics of the areas that are most susceptible to landslides, due to the similarity of LULC in the study area for the year 2019 (Table 3). 
Table 3. Evolution of LULC in the Paraitinga watershed.

\begin{tabular}{|c|c|c|c|c|c|c|c|c|c|}
\hline & \multicolumn{2}{|c|}{2002} & \multicolumn{2}{|c|}{2019} & \multicolumn{2}{|c|}{2036} & \multicolumn{3}{|c|}{$\Delta$} \\
\hline & $\begin{array}{l}\text { Area } \\
\left(\mathrm{km}^{2}\right)\end{array}$ & $\%$ & $\begin{array}{l}\text { Area } \\
\left(\mathrm{km}^{2}\right)\end{array}$ & $\%$ & $\begin{array}{l}\text { Area } \\
\left(\mathrm{km}^{2}\right)\end{array}$ & $\%$ & $\begin{array}{c}2002-2019 \\
(\%)\end{array}$ & $\begin{array}{c}2002-2036 \\
(\%)\end{array}$ & $\begin{array}{c}2019-2036 \\
(\%)\end{array}$ \\
\hline $\begin{array}{c}\text { Native } \\
\text { vegetation }\end{array}$ & 782.9 & 28.4 & 791.8 & 28.7 & 774.5 & 28.1 & 1.1 & -1.1 & -2.2 \\
\hline Reforestation & 94.1 & 3.4 & 242.9 & 8.8 & 257.5 & 9.3 & 158.2 & 173.7 & 6.0 \\
\hline $\begin{array}{l}\text { Urbanization/ } \\
\text { Bare soil }\end{array}$ & 72.5 & 2.6 & 232.7 & 8.4 & 237.0 & 8.6 & 221.0 & 227.0 & 1.9 \\
\hline Water bodies & 19.4 & 0.7 & 18.4 & 0.7 & 16.9 & 0.6 & -5.2 & -13.1 & -8.3 \\
\hline Field/Pasture & 1788.9 & 64.9 & 1471.9 & 53.4 & 1471.9 & 53.4 & -17.7 & -17.7 & 0.0 \\
\hline Total & 2757.8 & 100 & 2757.8 & 100 & 2757.8 & 100 & 0 & 0 & 0 \\
\hline
\end{tabular}

Analyzing the municipalities with medium and high frequency of landslides, Paraibuna has a predominance of fields and pastures $(36.1 \%)$, and relief with a slope greater than $30^{\circ}$ (Figure 3). This fact supposes that landslides may be primarily related to natural conditions such as terrain slope and LULC because this region is inserted in an area that has a stability classification that ranges from medium to unstable with respect to the occurrence of landslides.

The municipality of São Luiz do Paraitinga has a predominance of fields and pastures (55.6\%) and complex terrain, and in the center of the region there is a predominance of reliefs with up to $30^{\circ}$ of slope, and stable areas in relation to landslides. However, the portions to the north (Serra de Quebra-Cangalha mountains) and south (Serra do Mar mountains) have large areas with an inclination of more than $40^{\circ}$, an unstable area with occurrence of landslides (Figure 3).

\subsection{Distribution of precipitation in the Paraitinga watershed}

The total average precipitation for the period 1971-2000 for the study area was $1363.0 \mathrm{~mm}$, a result similar to the climatological normal for the municipality of Taubaté/SP which has an average rainfall of $1360.9 \mathrm{~mm}$ (INMET, 2019) and also to the results obtained by Silva and Fisch (2019) of $1363.1 \mathrm{~mm}$. Precipitation in the rainy season (October to March in the southern hemisphere) is $917.1 \mathrm{~mm}$, and in the summer period (December to February) is $493.9 \mathrm{~mm}$, results similar to those obtained by Horikoshi and Fisch (2007), Santos and Fisch (2016) and Brasiliense et al. (2020).

For the period 2021-2050 the average precipitation was $1338.9 \mathrm{~mm}$, which represents a decrease of $-1.8 \%$ between the analyzed periods, a result similar to that found by Chou et al. (2014b) and Lyra et al. (2018). The rainfall in the rainy season was predicted to be $875.4 \mathrm{~mm}$, which represents a decrease of $-4.5 \%$ between the analyzed periods, and for the summer period it was $441.2 \mathrm{~mm}$, a decrease of $-10.7 \%$. The comparative analysis between the rainy periods shows that, despite the decrease in precipitation being $-1.8 \%$, the greatest decreases will occur in the summer period, the time of the year that is most favorable for the occurrence of natural disasters related to landslides.

When analyzing the monthly rainfall averages between the past and future periods, it was observed that in winter (June) there was an increase in precipitation of $46.5 \%$, while in July this increase was $16.3 \%$. It is noteworthy that the monthly values of these months are small, on the order of 30-40 mm, and therefore even a small rain event between 5 to $10 \mathrm{~mm}$ would cause a significant increase in their relative values.

In the rainy season, there was an increase of precipitation in September $(11.1 \%)$ and October $(25.9 \%)$, while in all other months there was an average monthly decrease. In the summer period there was a decrease in rainfall averages during all months, with decreases of $6.25 \%,-12.6 \%$ and $-13.6 \%$ in December, January, and February, respectively (Figure 4). 


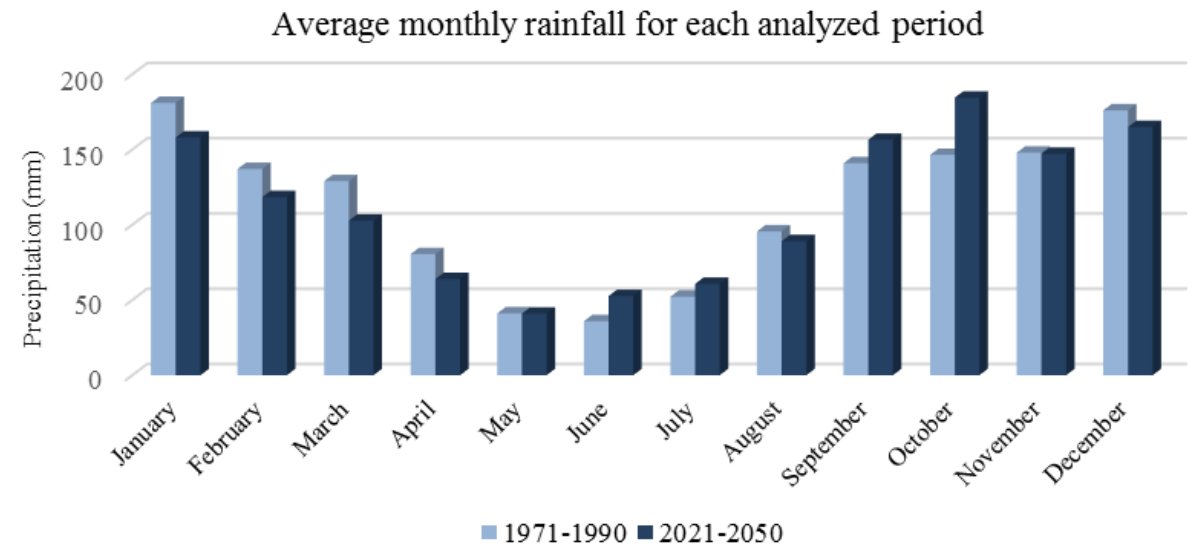

Figure 4. Average monthly rainfall in the Paraitinga Watershed.

When analyzing rainfall between the past and future periods (Figure 5) there was no significant change in the irregular distribution of precipitation in the Paraitinga Watershed, with the values demonstrating a high correlation between the analyzed periods, a similar result to that obtained by Silva and Simões (2014) and Silva et al. (2020).

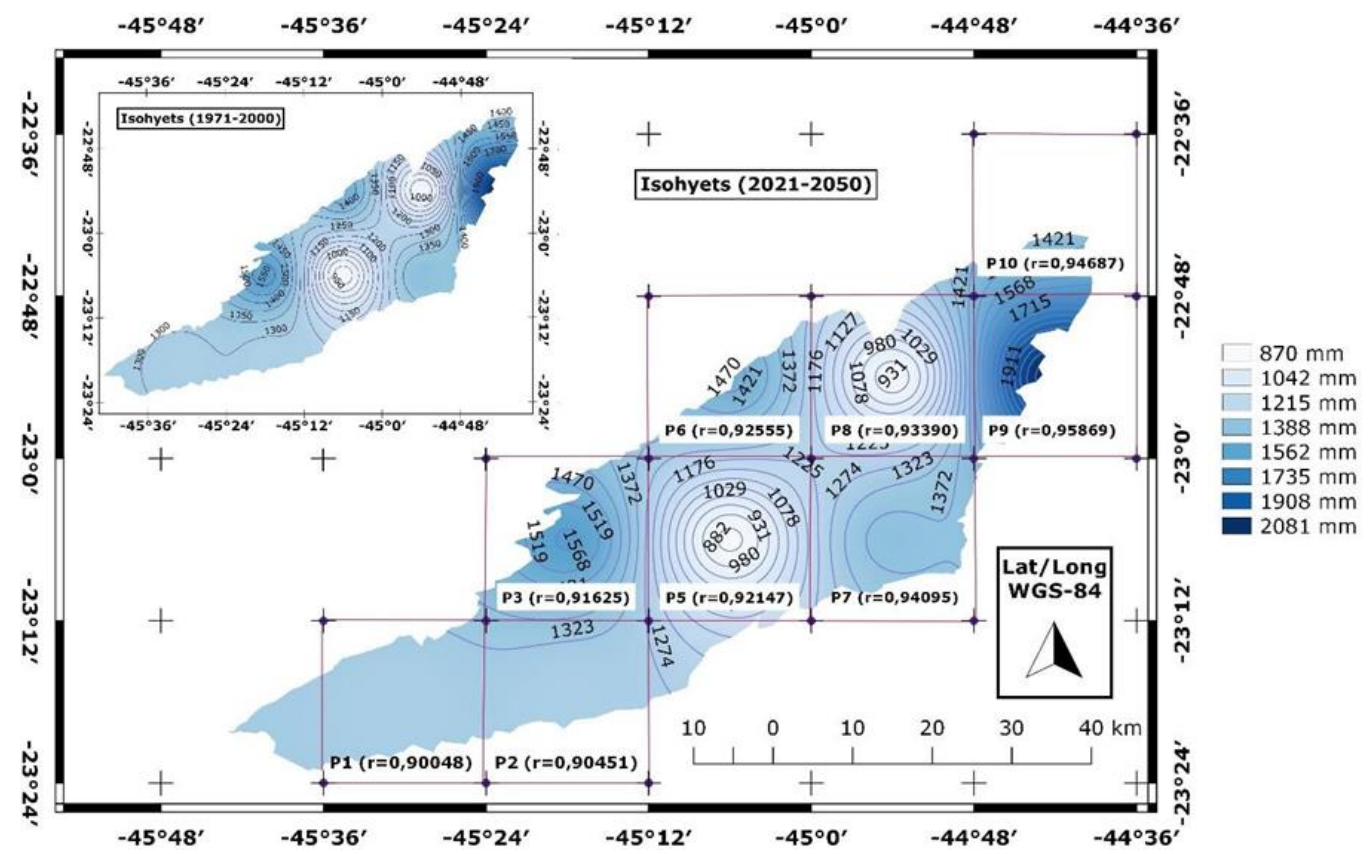

Figure 5. Distribution of precipitation and Pearson's Correlation Test between the analyzed periods in the Paraitinga Watershed.

Examining the rainfall by the simulated grid in the past period during the rainy season, the time of the year most favorable for the occurrence of landslides (Table 4), the location with the highest precipitation was $\mathrm{P}_{9}(1452.0 \mathrm{~mm})$ located in the extreme northeast of the region, in the regions of the Serra da Bocaina mountains and Serra do Mar mountains, which has a strong influence on orographic precipitation. This region presents a low frequency of landslides due to the low presence of urbanized areas and bare soil (8.97\%).

Precipitation in the rainy season at points $\mathrm{P}_{3}(1061.8 \mathrm{~mm}), \mathrm{P}_{6}(1000.0 \mathrm{~mm})$ and $\mathrm{P}_{9}$ $(1452.0 \mathrm{~mm})$ are located in the region with the highest altitudes in the study area, with grid $\mathrm{P}_{3}$ having a high incidence of landslides, in the municipality of São Luiz do Paraitinga, where there is a predominance of LULC of fields and pastures (52.2\%), complex terrain and the presence of cuts and embankments in the slope. These data suggest that there is a direct relationship 
between the presence of areas with no shrub vegetation and the occurrence of landslides.

Table 4. Precipitation by simulated grid and analyzed periods

\begin{tabular}{cccccccccc}
\hline & \multicolumn{3}{c}{$\begin{array}{c}\text { Average precipitation } \\
(\mathbf{m m})\end{array}$} & \multicolumn{3}{c}{$\begin{array}{c}\text { Average precipitation } \\
\text { in rainy season }(\mathbf{m m})\end{array}$} & \multicolumn{3}{c}{$\begin{array}{c}\text { Average precipitation in } \\
\text { summer season }\end{array}$} \\
\hline \multirow{2}{*}{ Grid } & $1971-$ & $2021-$ & $\Delta$ & $1971-$ & $2021-$ & $\Delta$ & $1971-$ & $2021-$ & $\Delta$ \\
& 2000 & 2050 & $(\%)$ & 2000 & 2050 & $(\%)$ & 2000 & 2050 & $(\%)$ \\
\hline $\mathbf{P}_{1}$ & 1285.7 & 1278.2 & -0.6 & 855.4 & 811.8 & -5.1 & 472.0 & 403.6 & -14.5 \\
$\mathbf{P}_{\mathbf{2}}$ & 1280.2 & 1262.9 & -1.4 & 836.3 & 791.7 & -5.3 & 448.0 & 390.1 & -12.9 \\
$\mathbf{P}_{\mathbf{3}}$ & 1573.6 & 1576.8 & 0.2 & 1061.8 & 1030.5 & -2.9 & 579.9 & 520.7 & -10.2 \\
$\mathbf{P}_{\mathbf{5}}$ & 869.2 & 857.1 & -1.4 & 559.8 & 522.4 & -6.7 & 292.0 & 243.3 & -16.7 \\
$\mathbf{P}_{\mathbf{6}}$ & 1480.2 & 1481.1 & 0.1 & 1000.0 & 971.5 & -2.8 & 539.0 & 485.3 & -10.0 \\
$\mathbf{P}_{7}$ & 1391.3 & 1344.3 & -3.4 & 932.5 & 877.9 & -5.9 & 498.7 & 447.5 & -10.3 \\
$\mathbf{P}_{\mathbf{8}}$ & 904.2 & 886.5 & -2.0 & 590.6 & 551.6 & -6.6 & 306.0 & 260.0 & -15.0 \\
$\mathbf{P}_{9}$ & 2100.8 & 2044.9 & -2.7 & 1452.0 & 1410.4 & -2.9 & 785.2 & 753.2 & -4.1 \\
$\mathbf{P}_{10}$ & 1381.7 & 1318.0 & -4.6 & 965.3 & 910.3 & -5.7 & 524.0 & 467.0 & -10.9 \\
Average & 1363.0 & 1338.9 & -1.8 & 917.1 & 875.4 & -4.5 & 493.9 & 441.2 & -10.7 \\
\hline
\end{tabular}

Precipitation in grid $\mathrm{P}_{1}(855.4 \mathrm{~mm})$, located in the municipality of Paraibuna has a medium frequency of landslides, where LULC is predominantly fields and pastures (39.1\%), and slope greater than $30^{\circ}$, again suggesting the relationship between slope and occurrence of landslides.

For the future period, the irregular spatial distribution of precipitation remained throughout the Paraitinga Watershed. The results point to the maintenance of high volumes of precipitation in the rainy season for grids $\mathrm{P}_{1}(811.8 \mathrm{~mm})$ with medium frequency of landslide occurrence and $\mathrm{P}_{3}(1030.5 \mathrm{~m})$ with high frequency.

\subsection{Delimitation of extreme rainfall}

The Quantis technique was used to characterize the rainfall intensity for both periods (past and future) and data were classified according to Table 5.

Table 5. Classification of precipitation by the Quantis technique.

\begin{tabular}{cccc}
\hline Quantis & Precipitation classification & Variation of Quantis & Variation $(\mathbf{m m})$ \\
\hline $\mathrm{Q}(0.15)$ & Very mild & $\mathrm{x} \leq 0.15$ & $\mathrm{x} \leq 10.2 \mathrm{~mm}$ \\
$\mathrm{Q}(0.35)$ & Mild & $0.15<\mathrm{x} \leq \mathrm{Q} 0.35$ & $10.2 \mathrm{~mm} \leq \mathrm{x} \geq 23.8 \mathrm{~mm}$ \\
$\mathrm{Q}(0.50)$ & Normal & $0.35<\mathrm{x}<\mathrm{Q} 0.65$ & $23.8 \mathrm{~mm} \leq \mathrm{x} \geq 44.0 \mathrm{~mm}$ \\
$\mathrm{Q}(0.65)$ & Intense & $0.65 \leq \mathrm{x}<\mathrm{Q} 0.85$ & $44.0 \mathrm{~mm} \leq \mathrm{x} \geq 57.6 \mathrm{~mm}$ \\
$\mathrm{Q}(0.85)$ & Very intense & $\mathrm{x} \geq 0.85$ & $\mathrm{x} \geq 57.6 \mathrm{~mm}$ \\
\hline
\end{tabular}

Source: PINKAYAN, 1966

In the past period, the highest number of occurrences of intense and very intense rainfall was in grid $\mathrm{P}_{8}$ ( 77 occurrences), located northeast of the study area and at the beginning of the elevation of the Serra do Mar mountains, followed by grid $\mathrm{P}_{3}$ (22 occurrences), a region of high frequency of landslides and $\mathrm{P}_{7}(20$ occurrences).

For the future period, the grid of greatest occurrence of intense and very intense rainfall was predicted to be grid $\mathrm{P}_{9}$ (62 occurrences) located in the high altitudes of the Serra da Bocaina mountains and Serra do Mar mountains, followed by grid $\mathrm{P}_{3}$ (30 occurrences) and grids $\mathrm{P}_{5}$ and $\mathrm{P}_{6}$ (24 occurrences), a region of high frequency of landslides in the municipality of São Luiz do Paraitinga.

The results indicate that there will be a tendency for change in the occurrence of intense and very intense rainfall between grids $\mathrm{P}_{8}$ and $\mathrm{P}_{9}$ when comparing the past and future periods, followed by an increase in the average of this type of precipitation (Table 6). 
Table 6. Occurrence and comparison between the analyzed periods of intense and very intense rainfall.

\begin{tabular}{cccc}
\hline & $\mathbf{1 9 7 1 - 2 0 0 0}$ & $\mathbf{2 0 2 1 - 2 0 5 0}$ & $\mathbf{1 9 7 1 - 2 0 0 0}$ to 2021-2050 \\
\hline Grid & Occurrence & Occurrence & $\Delta \%$ \\
\hline $\mathbf{P}_{\mathbf{1}}$ & 15 & 22 & $46.7 \%$ \\
$\mathbf{P}_{\mathbf{2}}$ & 13 & 12 & $-7.7 \%$ \\
$\mathbf{P}_{\mathbf{3}}$ & 22 & 30 & $36.4 \%$ \\
$\mathbf{P}_{\mathbf{5}}$ & 8 & 24 & $200.0 \%$ \\
$\mathbf{P}_{\mathbf{6}}$ & 12 & 24 & $100.0 \%$ \\
$\mathbf{P}_{\mathbf{7}}$ & 20 & 19 & $-5.0 \%$ \\
$\mathbf{P}_{\mathbf{8}}$ & 77 & 7 & $-90.9 \%$ \\
$\mathbf{P}_{\mathbf{9}}$ & 4 & 62 & $1450.0 \%$ \\
$\mathbf{P}_{\mathbf{1 0}}$ & 10 & 12 & $20.0 \%$ \\
\hline Average & 20.1 & 23.5 & 194.3 \\
\hline
\end{tabular}

Allied to the increase in the occurrence of intense and very intense rainfall (194.3\%), there will be an increase of $13.3 \%$ in consecutive dry days (CDD) when comparing the past and future periods. In all simulation grids there will be an increase in $\mathrm{CDD}$, with grid $\mathrm{P}_{3}$ having the lowest CDD increase $(5.11 \%)$, and the highest in grid $\mathrm{P}_{8}(25.11 \%)$.

The occurrence of very wet days (R95p) will increase by $0.7 \%$ when comparing the past and future periods, with rainfall with percentiles above the $95^{\text {th }}$ predicted to occur with the same frequency when comparing the analyzed periods. The R95p had great variability in the study area with some simulation grids increasing and others decreasing.

The grids of greatest increase in $\mathrm{R} 95 \mathrm{p}\left(\mathrm{P}_{1}, \mathrm{P}_{3}, \mathrm{P}_{5}\right.$ and $\left.\mathrm{P}_{6}\right)$ are in the municipalities of Paraibuna and São Luiz do Paraitinga, where there is a medium and high frequency of landslides. This indicates that there is a probable tendency to increase the frequency of landslides, since the increase in the $95^{\text {th }}$ percentile precipitation events will occur in the most propitious areas for landslides.

The Maximum 5-day precipitation amount (Rx5day) demonstrates an increase of $15.8 \%$ between the past and future periods, but with certain specificities that need to be analyzed. The grid $\mathrm{P}_{7}$ is in the northeast region of the study area and was the only one with an increase between the periods analyzed, which was very intense $(160.8 \%)$. The results indicate that grid $\mathrm{P}_{7}$ will be strongly influenced by the Atlantic Ocean, with an increase in the frequency of uninterrupted rainy days. The results from other simulation grids demonstrate a decrease of Rx5day when comparing the past and future periods. If the grid $\mathrm{P}_{7}$ was excluded from the average, the decrease between the analyzed periods would be $-2.3 \%$ (Table 7 ).

Table 7. ETCDDI index in the study area

\begin{tabular}{cccccccccc}
\hline & \multicolumn{3}{c}{ CDD (days) } & \multicolumn{3}{c}{ R95p (mm) } & \multicolumn{3}{c}{ Rx5day (mm) } \\
\hline Grid & $1971-2000$ & $2021-2050$ & $\Delta \%$ & $1971-2000$ & $2021-2050$ & $\Delta \%$ & $1971-2000$ & $2021-2050$ & $\Delta \%$ \\
\hline $\mathbf{P}_{\mathbf{1}}$ & 18.7 & 21.3 & 13.7 & 231.3 & 239.0 & 3.3 & 100.8 & 99.7 & -1.1 \\
$\mathbf{P}_{\mathbf{2}}$ & 16.6 & 18.1 & 9.0 & 235.6 & 235.3 & -0.1 & 94.8 & 88.1 & -7.1 \\
$\mathbf{P}_{\mathbf{3}}$ & 18.3 & 19.2 & 5.1 & 268.5 & 282.2 & 5.1 & 113.3 & 111.3 & -1.8 \\
$\mathbf{P}_{\mathbf{5}}$ & 22.4 & 24.8 & 10.8 & 163.5 & 165.8 & 1.4 & 71.4 & 72.7 & 1.8 \\
$\mathbf{P}_{\mathbf{6}}$ & 17.7 & 20.0 & 12.5 & 253.8 & 266.5 & 5.0 & 103.5 & 103.2 & -0.2 \\
$\mathbf{P}_{7}$ & 16.4 & 17.7 & 7.7 & 262.9 & 255.1 & -3.0 & 97.8 & 255.1 & 160.8 \\
$\mathbf{P}_{\mathbf{8}}$ & 19.6 & 24.6 & 25.1 & 173.0 & 170.0 & -1.7 & 71.7 & 71.6 & -0.1 \\
$\mathbf{P}_{9}$ & 14.4 & 16.6 & 15.1 & 394.8 & 386.2 & -2.2 & 147.6 & 140.7 & -4.7 \\
$\mathbf{P}_{10}$ & 17.8 & 21.6 & 21.1 & 244.3 & 240.5 & -1.6 & 86.3 & 81.8 & -5.2 \\
\hline Average & 18.0 & 20.4 & 13.3 & 247.5 & 249.0 & 0.7 & 98.6 & 113.8 & 15.8 \\
\hline
\end{tabular}


This indicates that the precipitation events tend to be more concentrated, increasing the occurrence of landslides specifically in the areas where they occur with medium and high frequency (municipalities of Paraibuna and São Luiz do Paraitinga), especially when combined with the increase in 3-day consecutive precipitation events.

For the definition of the landslide trigger threshold, the PPDC parameters were used, which were developed by Santoro et al. (2010), and which consider the accumulated rainfall in 72 hours as the main trigger of landslides.

The results suggest that in the past period the grid $\mathrm{P}_{9}$ had the highest occurrence of accumulated precipitation in 72 hours (63 occurrences above the threshold) and low frequency of landslides due to the low presence of urbanized areas and bare soil. The other grids that had greater occurrence of precipitation above the thresholds that trigger landslides were $\mathrm{P}_{1}, \mathrm{P}_{3}, \mathrm{P}_{6}$ and $\mathrm{P}_{7}$, which are located in the municipalities of Paraibuna and São Luiz do Paraitinga, which have medium and high frequency of landslides, respectively, thus justifying their occurrence.

For the future period, the models predicted the permanence of the areas with the highest occurrence of accumulated precipitation above the threshold that triggers landslides, with the grid $\mathrm{P}_{9}$ having the highest incidence ( 49 occurrences above the threshold). However, the grids located in the areas of medium and high frequency of landslides will suffer a strong increase in precipitation above the threshold that triggers landslides $\left(\mathrm{P}_{1} 60.0 \%, \mathrm{P}_{3} 25.0 \%\right.$ and $\left.\mathrm{P}_{6} 40.0 \%\right)$.

The comparison between the past and future periods indicates a strong increase $(31.8 \%)$ in the occurrence of precipitation above the threshold of 72 hours of accumulated precipitation that triggers landslides, as used by the PPDC. If considering only the grids located in the municipalities with medium and high frequency of landslides this increase may reach $41.6 \%$ by 2050 (Table 8).

Table 8. Incidence of accumulated precipitation above the threshold that triggers landslides.

\begin{tabular}{|c|c|c|c|c|c|c|c|c|c|}
\hline & \multicolumn{3}{|c|}{ (1971-2000) } & \multicolumn{3}{|c|}{$(2021-2050)$} & \multicolumn{3}{|c|}{$\Delta$} \\
\hline & $24 \mathrm{~h}$ & $48 \mathrm{~h}$ & $72 \mathrm{~h}$ & $24 \mathrm{~h}$ & $48 \mathrm{~h}$ & $72 \mathrm{~h}$ & $24 \mathrm{~h}$ & $48 \mathrm{~h}$ & $72 \mathrm{~h}$ \\
\hline Grids & $60 \mathrm{~mm}$ & $80 \mathrm{~mm}$ & $100 \mathrm{~mm}$ & $60 \mathrm{~mm}$ & $80 \mathrm{~mm}$ & $100 \mathrm{~mm}$ & $60 \mathrm{~mm}$ & $80 \mathrm{~mm}$ & $100 \mathrm{~mm}$ \\
\hline $\mathbf{P}_{1}$ & 4 & 6 & 5 & 3 & 6 & 8 & $-25.0 \%$ & $0.0 \%$ & $60.0 \%$ \\
\hline $\mathbf{P}_{2}$ & 3 & 5 & 3 & 1 & 4 & 3 & $-66.7 \%$ & $-20.0 \%$ & $0.0 \%$ \\
\hline $\mathbf{P}_{3}$ & 3 & 5 & 8 & 5 & 10 & 10 & $66.7 \%$ & $100.0 \%$ & $25.0 \%$ \\
\hline $\mathbf{P}_{5}$ & 2 & 3 & 2 & 1 & 3 & 3 & $-50.0 \%$ & $0.0 \%$ & $50.0 \%$ \\
\hline $\mathbf{P}_{6}$ & 3 & 4 & 5 & 2 & 9 & 7 & $-33.3 \%$ & $125.0 \%$ & $40.0 \%$ \\
\hline $\mathbf{P}_{7}$ & 3 & 8 & 5 & 2 & 6 & 5 & $-33.3 \%$ & $-25.0 \%$ & $0.0 \%$ \\
\hline $\mathbf{P}_{8}$ & 1 & 1 & 1 & 1 & 3 & 3 & $0.0 \%$ & $200.0 \%$ & $200.0 \%$ \\
\hline $\mathbf{P}_{9}$ & 9 & 47 & 63 & 18 & 33 & 49 & $100.0 \%$ & $-29.8 \%$ & $-22.2 \%$ \\
\hline $\mathbf{P}_{10}$ & 1 & 4 & 3 & 0 & 0 & 1 & $-33.30 \%$ & $-100.0 \%$ & $-66.7 \%$ \\
\hline Average & 3.2 & 9.2 & 10.6 & 10.8 & 8.2 & 9.9 & $-15.7 \%$ & $27.8 \%$ & $31.8 \%$ \\
\hline
\end{tabular}

\section{CONCLUSIONS}

This study conducted an analysis of the change in precipitation between the past (19712000) and the future (2021-2050) in order to analyze the profile of rainfall in the study area, which is one of the main elements that triggers landslides. 
The results predict that there will be an increase in consecutive dry days (13.3\%), followed by a large increase in the occurrence of intense and very intense rainfall (194.3\%) when comparing the analyzed periods, pointing to a future scenario of intense and concentrated rainfall without major changes in land use and cover in the future.

The accumulated rainfall of 72 hours obtained in this study and used as a critical operational threshold for the triggering of landslides by São Paulo State Civil Defense Preventive Plan predicts an increase in the occurrence of landslides of $31.8 \%$ comparing the past and future periods, and in the municipalities with medium and high frequency of landslides (Paraibuna and São Luiz do Paratinga) the increase of precipitation of 72 hours that triggers landslides will be $41.6 \%$ by 2050 .

\section{REFERENCES}

AB'SÁBER, A. N. Os domínios de natureza no Brasil: potencialidades paisagísticas. v. 1. São Paulo: Ateliê Editorial, 2003.

AGEVAP. Áreas vulneráveis e eventos extremos críticos, 2013. Available at: https://www.agevap.org.br/ Access: 30 May 2020.

ALEXANDER, L. V. Global observed long-term changes in temperature and precipitation extremes: a review of progress and limitations in IPCC assessments and beyond. Weather and Climate Extremes, v. 11, p. 4-16, 2016. https://doi.org/10.1016/j.wace.2015.10.007

ALEXANDER, L. V.; FOWLER, H. J.; BADOR, M.; BEHRANGI, A.; DONAT, M. G.; DUNN, R.; FUNK, C.; GOLDIE, J.; LEWIS, E.; ROGÉ, M.; SENEVIRATNE, S. I.; VENUGOPAL, V. On the use of indices to study extreme precipitation on sub-daily and daily timescales. Environmental Research Letters, v. 14, n. 12, p. 125008, 2019. https://doi.org/10.3929/ethz-b-000404244

ALEXANDER, L.; HEROLD, N. ClimPACT2 Indices and software: A document prepared on behalf of The Commission for Climatology $(\mathrm{CCl})$ Expert Team on Sector-Specific Climate Indices (ET-SCI), 2016. Available at: https://epic.awi.de/id/eprint/49274/1/ClimPACTv2_manual.pdf. Access: 25 Mar. 2020.

ALMEIDA, L. Q.; WELLE, T.; BIRKMANN, J. Disaster risk indicators in Brazil: a proposal based on the world risk index. International journal of disaster risk reduction, v. 17, p. 251-272, 2016. https://doi.org/10.1016/j.ijdrr.2016.04.007

BATISTA, J. A.N.; JULIEN, P. Y. Remotely sensed survey of landslide clusters: Case study of Itaoca, Brazil. Journal of South American Earth Sciences, v. 92, p. 145-150, 2019. https://doi.org/10.1016/j.jsames.2019.02.021

BRASILIENSE, C. S.; DERECZYNSKI, C. P.; SATYAMURTY, P., CHOU, S. C.; CALADO, R. N. Climatológicas da Temperatura do Ar e da Precipitação na Bacia do Rio Paraíba do Sul, Região Sudeste do Brasil. Anuário do Instituto de Geociencias, v. 43, n. 1, 2020.

CAMARINHA. P. I. M.; CANAVESI. V.; ALVALÁ. R. C. S. Shallow landslide prediction and analysis with risk assessment using a spatial model in a coastal region in the state of São Paulo, Brazil. Natural Hazards and Earth System Sciences. v. 14. p. 2449-2468, 2014. https://dx.doi.org/10.5194/nhess-14-2449-2014 
CHANDER. G.; MARKHAM. B. L.; HELDER. D. L. Summary of current radiometric calibration coefficients for Landsat MSS. TM. ETM+. and EO-1 ALI sensors. Remote $\begin{array}{llllllll}\text { sensing of environment, } & \text { v. 113, n. 5, p. 893-903, }\end{array}$ https://doi.org/10.1016/j.rse.2009.01.007

CHOU, S.C.; LYRA, A.; MOURÃO, C.; DERECZYNSKI, C.; PILOTTO, I.; GOMES, J.; BUSTAMANTE, J.; TAVARES, P.; SILVA, A.; RODRIGUES, D.; CAMPOS, D.; CHAGAS, D.; SUEIRO, G.; SIQUEIRA, G.; MARENGO, J. Assessment of Climate Change over South America under RCP 4.5 and 8.5 Downscaling Scenarios. American $\begin{array}{lllllll}\text { Journal of Climate } & \text { Change, v. 3, p. 512-527, } 2014 \mathrm{~b} .\end{array}$ https://dx.doi.org/10.4236/ajcc.2014.35043

CHOU, S. C.; LYRA, A.; MOURÃO, C.; DERECZYNSKI, C.; PILOTTO, I.; GOMES, J.; BUSTAMANTE, J.; TAVARES, P.; SILVA, A.; RODRIGUES, D.; CAMPOS, D.; CHAGAS, D.; SUEIRO, G.; SIQUEIRA, G.; NOBRE, P.; MARENGO, J. Evaluation of the Eta Simulations Nested in Three Global Climate Models. American Journal of Climate Change, v. 3. p. 438-454. 2014a. https://dx.doi.org/10.4236/ajcc.2014.35039

HORIKOSHI, A. S.; FISCH, G. F. Balanço hídrico atual e simulações para cenários climáticos futuros no município de Taubaté, SP, Brasil. Revista Ambiente \& Água, v. 2, n. 2, p. 33-46, 2007. https://dx.doi.org/10.4136/ambi-agua.25

HUGHES, K. S.; SCHULZ, W. Map depicting susceptibility to landslides triggered by intense rainfall, Puerto Rico. U.S. Geological Survey Open-File Report 2020-1022. Washington, DC.: USGS, 2020. 91 p. https://doi.org/10.3133/ofr20201022

IBGE. Download Geociências: Cartas topográfica. Available at: https://www.ibge.gov.br/geociencias/downloads-geociencias.html. Access: 02 Nov. 2019.

INMET. Normais climatológica (1981-2010). Available at: http://www.inmet.gov.br/portal/index.php?r=clima/normaisClimatologicas. Access: 20 Oct. 2019.

INPE. Topodata: banco de dados geomorfométricos do Brasil. Available at: http://www.dsr.inpe.br/topodata/. Access: 03 Nov. 2019.

KÖNIG, T.; KUX, H. J. H.; MENDES, R. M. Shalstab mathematical model and WorldView-2 satellite images to identification of landslide-susceptible areas. Natural Hazards, v. 97, n. 3, p. 1127-1149, 2019. https://doi.org/10.1007/s11069-019-03691-4

LYRA, A.; TAVARES, P.; CHOU, S. C.; SUEIRO, G.; DERECZYNSKI, C. P.; SONDERMANN, M.; SILVA, A.; MARENGO, J.; GIAROLLA, A. Climate change projections over three metropolitan regions in Southeast Brazil using the non-hydrostatic Eta regional climate model at 5-km resolution. Theoretical and applied climatology, $\mathrm{v}$. 132, n. 1-2, p. 663-682, 2018. https://doi.org/10.1007/s00704-017-2067-z

MARENGO, J. O futuro clima do Brasil. Revista USP, n. 103, p. 25-32, 2014.

MARENGO, J. A.; ALVES, L. M. Tendências hidrológicas da bacia do rio Paraíba do sul. Revista Brasileira de Meteorologia, v. 20, n. 2, p. 215-226, 2005. 
MENDES, R. M.; ANDRADE, M. R. M.; TOMASELLA, J.; MORAES, M. A. E.; SCOFIELD, G. B. Understanding shallow landslides in Campos do Jordão municipality-Brazil: disentangling the anthropic effects from natural causes in the disaster of 2000. Natural Hazards \& Earth System Sciences, v. 18, n. 1, 2018. https://doi.org/10.5194/nhess-18$15-2018$

MENDES, R. M.; de ANDRADE, M. R. M.; GRAMINHA, C. A.; PRIETO, C. C.; ÁVILA, F. F.; CAMARINHA, P. I. M. Stability analysis on urban slopes: Case study of an anthropogenic-induced landslide in São José dos Campos, Brazil. Geotechnical and

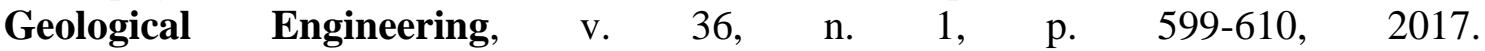
https://www.researchgate.net/deref/http\%3A\%2F\%2Fdx.doi.org\%2F10.1007\%2Fs1070 6-017-0303-z

MENDES, R. M.; VALERÍO FILHO, M.; BERTOLDO, M. A.; SILVA, M. F. Estudo de limiares críticos de chuva deflagradores de deslizamentos no município de São José dos Campos/SP (Brasil). Territorium, n. 22, p. 119-129, 2015. https://doi.org/10.14195/1647-7723_22_8

MOLINA, E. A. N.; CARDOSO, A. O.; NOGUEIRA, F. R. Relação PrecipitaçãoDeslizamento no Município de São Bernardo do Campo-SP. Ciência e Natura, v. 37, n. 1, p. 46-54, 2015. https://dx.doi.org/10.5902/2179460X16214

MOLUSCE. Landscape change analysis with MOLUSCE - methods and algorithms. Available at: https://wiki.gislab.info/w/Landscape_change_analysis_with_MOLUSCE_-_methods_and_algorithms. Access: 10 Apr. 2020.

NEXTGIS. Modules for Land Use Change Simulations. Available at: https://nextgis.com/. Access: 10 Apr. 2020.

NOAA. Trends in Atmospheric Carbon Dioxide. Available at: https://www.esrl.noaa.gov/gmd/ccgg/trends/global.html. Access: 17 July 2020.

OLIVEIRA, N. S.; ROTUNNO FILHO, O. C.; MARTON, E.; SILVA, C. Correlation between rainfall and landslides in Nova Friburgo, Rio de Janeiro-Brazil: a case study. Environmental Earth Sciences, v. 75, n. 20, p. 1358, 2016. https://doi.org/10.1007/s12665-016-6171-7

OLIVEIRA-FOLHARINI, S.; OLIVEIRA, R. C.; BROWN, L. C. Estimate of housing and population in landslide risk areas in California (USA) and coastal São Paulo (Brazil). Revista Geográfica de América Central, v. 3, n. 61E, p. 319-337, 2018. https://doi.org/10.15359/rgac.61-3.16

PINKAYAN, S. Conditional probabilities of occurrence of wet and dry years over a large continental area. Forty-Collins: Hydrology Colorado State University, 1966. (Paper Number 12.).

SANTORO, J.; MENDES, R. M.; PRESSINOTTI, M. M. N.; MANOEL, G. R.; MANOEL, G. dos R. Correlação entre chuvas e deslizamentos ocorridos durante a operação do plano preventivo de defesa civil em São Paulo, SP. In: SIMPÓSIO BRASILEIRO DE CARTOGRAFIA GEOTÉCNICA E GEOAMBIENTAL, 7., 2010, Maringá. Anais[...] Maringá: SBCGG, 2010. 
SANTOS, T. A.; FISCH, G. Temperatura e precipitação: futuros cenários do município de Taubaté, SP, Brasil. Revista Ambiente \& Água, v. 11, p. 1068-1087, 2016. http://dx.doi.org/10.4136/ambi-agua.1896

SÃO PAULO (Estado). Defesa Civil. Resolução CMIL/CEPDEC 21-610 do Plano Preventivo de Defesa Civil. Redefine e implanta o Plano Preventivo de Defesa Civil PPDC específico para escorregamentos de encostas na Região do Vale do Paraíba, Serra da Mantiqueira e Litoral Norte. 27 Nov. 2019. Available at: http://www.defesacivil.sp.gov.br/resolucoes-portarias-e-protocolos/. Access: 13 jul. 2020.

SILVA, R. C.; FISCH, G. Cenários hidroclimáticos futuros (2011-2040) para a represa de Paraibuna, SP, Brasil: subsídios para a transposição entre bacias hidrográficas. Geociências, v. 38, n. 2, p. 587-597, 2019.

SILVA, R. C.; FISCH, G. F.; SANTOS, T. A. Future scenarios (2011-2040) of temporal and spatial changes in precipitation in the Paraitinga and Paraibuna watersheds, São Paulo, Brazil. Revista Ambiente \& Água, v. 14, n. 7, p. 1-12, 2019. https://doi.org/10.4136/ambi-agua.2302

SILVA, R. C.; FISCH, G. F.; SANTOS, T. A. Geoprocessing and climate simulation applied to transposition between watersheds in São Paulo state, Brazil. Revista Agro@ mbiente On-line, v. 14, 2020. http://dx.doi.org/10.18227/1982-8470ragro.v14i0.5918

SILVA, W. M.; SIMÕES, S. J. C. Spatial Intra-Annual Variability of Precipitation Based on Geostatistics. A Case Study for the Para1ba do Sul Basin, Southeastern Brazil. International Journal of Geosciences, v. 5, p. 408-417, 2014. http://dx.doi.org/10.4236/ijg.2014.54039

SILVA DIAS, M. A. F. Eventos Climáticos Extremos. Revista USP, n. 103, p. 33-40. 2014. https://doi.org/10.11606/issn.2316-9036.v0i103p33-40

SILVESTRE, M. R. Técnicas estatísticas utilizadas em climatologia geográfica: diagnóstico e propostas. 2016. 408p. Tese (Doutorado em Geografia) - Universidade Estadual Paulista, Presidente Prudente, 2016.

TATIZANA, C.; OGURA, A. T.; CERRI, L. D. S.; ROCHA, M. D. Análise de correlação entre chuvas e escorregamentos-Serra do Mar, município de Cubatão. In: CONGRESSO BRASILEIRO DE GEOLOGIA DE ENGENHARIA, 5., 1987, São Paulo. Anais[...] São Paulo: ABGE, 1987a. p. 225-236.

TATIZANA, C.; OGURA, A. T.; CERRI, L. D. S.; ROCHA, M. D. Modelamento numérico da análise de correlação entre chuvas e escorregamentos aplicado às encostas da Serra do Mar no município de Cubatão. In: CONGRESSO BRASILEIRO DE GEOLOGIA DE ENGENHARIA, 5., 1987, São Paulo. Anais[...] São Paulo: ABGE, 1987b. p. 237-248.

UNITED STATES. Geological Survey. Earth Explorer. Available at: https://earthexplorer.usgs.gov/. Access: 25 Oct. 2019.

VERMOTE. E.; JUSTICE. C.; CLAVERIER. M.; FRANCH. B. Preliminary analysis of the performance of the Landsat 8/OLI land surface reflectance product. Remote Sensing of Environment, v. 185. p. 46-56. 2016. https://doi.org/10.1016/j.rse.2016.04.008 
VIEIRA, B. C.; FERNANDES, N. F.; AUGUSTO FILHO, O.; MARTINS, T. D.; MONTGOMERY, D. R. Assessing shallow landslide hazards using the TRIGRS and SHALSTAB models, Serra do Mar, Brazil. Environmental Earth Sciences, v. 77, n. 6, p. 260, 2018. https://doi.org/10.1007/s12665-018-7436-0

VIEIRA. B. C.; FERNANDES. N. F.; AUGUSTO FILHO, O. Shallow landslide prediction in the Serra do Mar. São Paulo. Brazil. Natural hazards and earth system sciences, v. 10, n. 9, p. 1829-1837, 2010. https://dx.doi.org/10.5194/nhess-10-1829-2010

WATANABE, M.; SUZUKI, T.; O'ISHI, R.; KOMURO, Y.; WATANABE, S.; EMORI, S. Improved Climate Simulation by MIROC5: Mean States. Variability and Climate

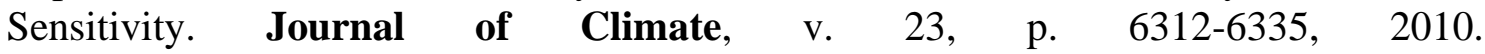
https://doi.org/10.1175/2010JCLI3679.1

XAVIER, T. M. B. S.; XAVIER, A. F. S.; ALVES, J. M. B. Quantis e eventos extremos: aplicações em ciências da terra e ambientais. Fortaleza: RDS, 2007. 278 p.

ZHANG, X.; YANG, F. RClimDex (1.0): User Manual. Climate Research Branch, Environment Canada, Downsview, Ontario, Canada, 2004. Available at: http://etccdi.pacificclimate.org/software.shtml. Access: 25 Mar. 2020. 